\title{
Day Times Picomole per Liter per Meter Squared
}

National Cancer Institute

\section{Source}

National Cancer Institute. Day Times Picomole per Liter per Meter Squared. NCI

Thesaurus. Code C111189.

Days times picomoles per liter, divided by meters squared. 